\title{
Analysis of indoleamine 2,3-dioxygenase 1 (IDO1) expression of cultured cord blood adherent mononuclear cells as an indicator of atopic risk
}

Yifei Zhu*, Jenny Thiele, Anne K Ellis

From Canadian Society of Allergy and Clinical Immunology Annual Scientific Meeting 2013

Toronto, Canada. 3-6 October 2013

\section{Background}

Maternal atopy is a known risk factor for allergy development in children. This link can be studied to find potential indicators of atopic risk by examining umbilical cord blood. Indoleamine 2,3-dioxygenase 1 (IDO1), the initiator of the IDO pathway, plays a regulatory role in the immune response and may differ in expression in the adherent mononuclear cells (AMNC)

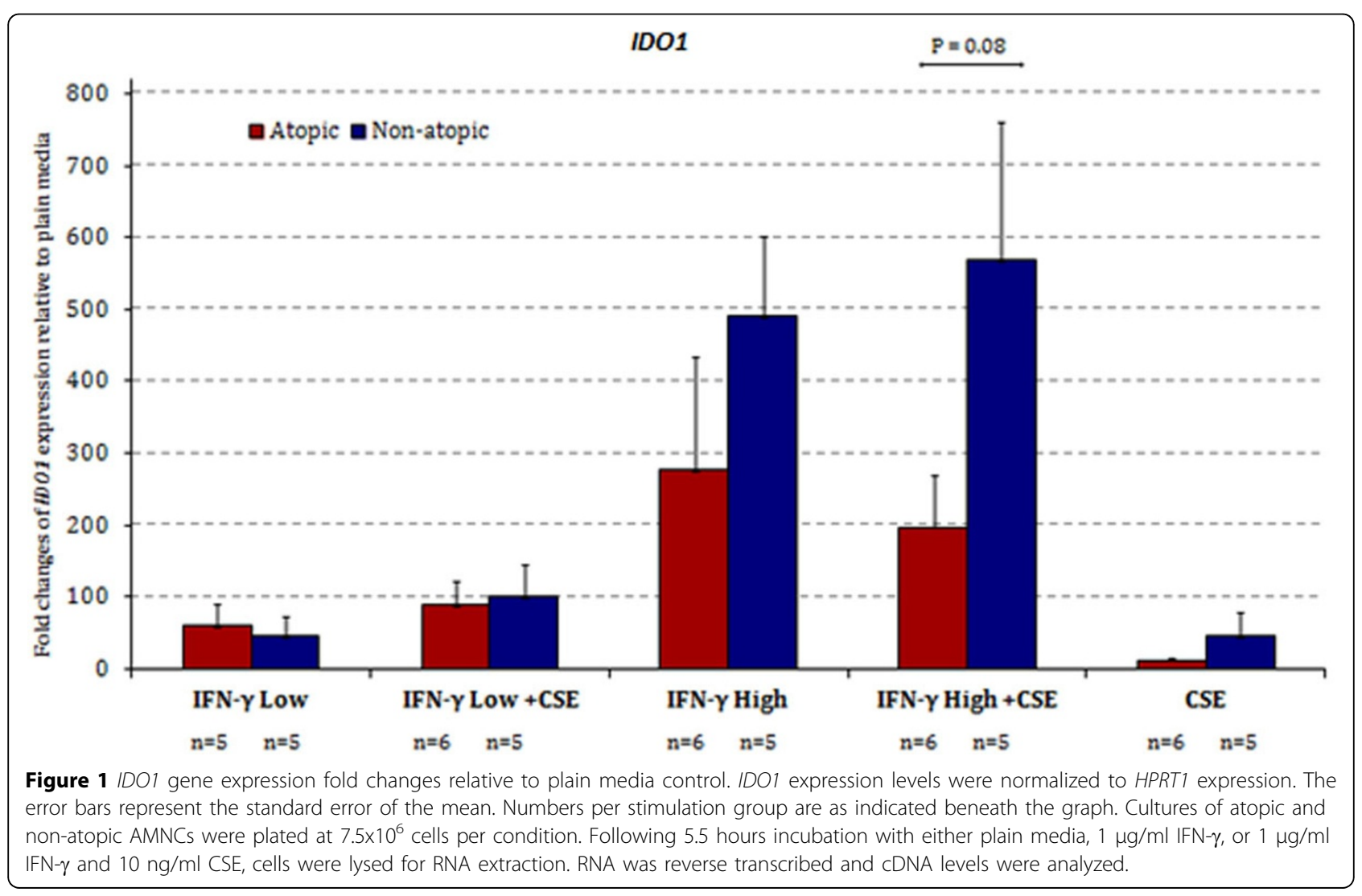

* Correspondence: 8yz7@queensu.ca

Department of Biomedical and Molecular Sciences/Medicine, Queen's

University, Kingston, ON, K7L 3N6, Canada

Ciolmed Central

(c) 2014 Zhu et al; licensee BioMed Central Ltd. This is an Open Access article distributed under the terms of the Creative Commons

Attribution License (http://creativecommons.org/licenses/by/2.0), which permits unrestricted use, distribution, and reproduction

in any medium, provided the original work is properly cited. The Creative Commons Public Domain Dedication waiver

(http://creativecommons.org/publicdomain/zero/1.0/) applies to the data made available in this article, unless otherwise stated. 

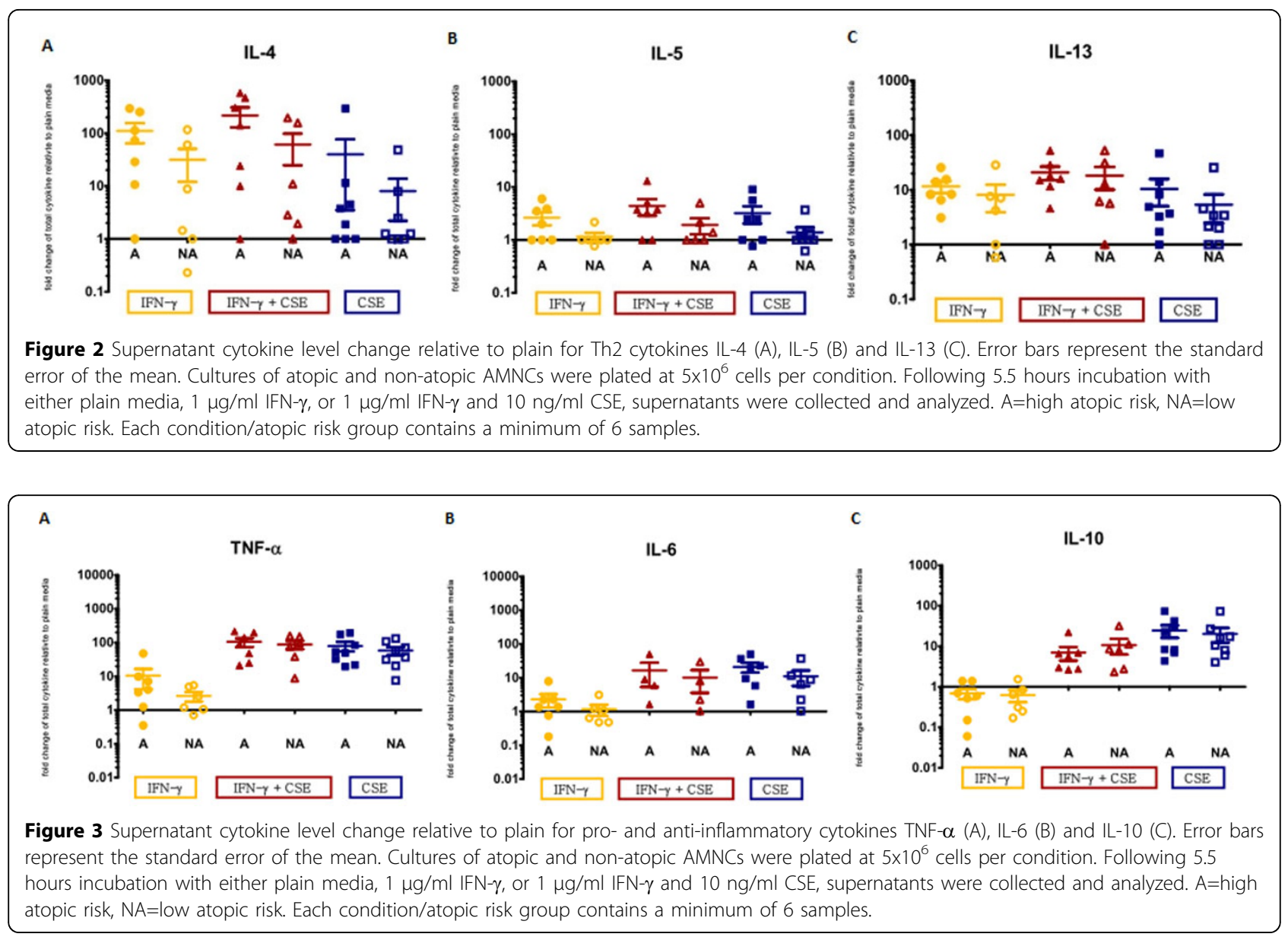

of atopic and non-atopic individuals. Supernatants of these AMNC cultures may also exhibit different cytokine profiles.

\section{Methods}

Cord blood samples were collected from consenting women undergoing elective Caesarian-sections and atopic status was self-reported. Mononuclear cells were isolated and cryopreserved. Once thawed, AMNCs were cultured and stimulated with interferon-gamma (IFN- $\gamma 1 \mu \mathrm{g} / \mathrm{ml}$ or $1 \mathrm{ng} / \mathrm{ml}$ ) with or without control standard endotoxin (CSE $10 \mathrm{ng} / \mathrm{ml}$ ). In each condition, $7.5 \times 10^{6}$ cells were seeded for gene analysis and $5 \times 10^{6}$ cells were seeded for cytokine analysis. Cells were lysed for RNA isolation, reverse transcribed and cDNA levels were analyzed using qPCR. Supernatant cytokine levels were analyzed using the Luminex ${ }^{\circledR} \mathrm{xMAP}^{\mathrm{TM}}$ Technology.

\section{Results}

IDO1 expression was significantly increased in all stimulated conditions $(\mathrm{P}<0.05)$ except for the CSE only condition. The high atopic risk group displayed trend towards decreased IDO1 expression, however, high and low atopic risk groups did not show significant differences (Figure 1). Supernatant cytokine analysis show heightened levels of Th2 cytokines IL-4, IL-5, IL-13 (Figure 2). Similarly, heightened levels of TNF- $\alpha$ and IL- 6 were observed, while levels of IL-10 were decreased in the high atopic risk samples in all stimulated conditions (Figure 3).

\section{Conclusions}

Preliminary differences detected suggest that further research could elucidate a suitable biomarker to predict atopic risk. Due to the lack of significant differences between high and low atopic risk groups for IDO1 expression and cytokine expression, a reliable biomarker was not determined in this study.

Published: 3 March 2014

doi:10.1186/1710-1492-10-S1-A72

Cite this article as: Zhu et al:: Analysis of indoleamine 2,3-dioxygenase 1 (IDO1) expression of cultured cord blood adherent mononuclear cells as an indicator of atopic risk. Allergy, Asthma \& Clinical Immunology 2014 10(Suppl 1):A72. 